\title{
NR1 H4 wt Allele
}

National Cancer Institute

\section{Source}

National Cancer Institute. NR1H4 wt Allele. NCI Thesaurus. Code C114911.

Human NR1H4 wild-type allele is located in the vicinity of $12 \mathrm{q} 23.1$ and is approximately

$91 \mathrm{~kb}$ in length. This allele, which encodes bile acid receptor protein, plays a role in both the metabolism of bile acids and ligand-dependent transcriptional regulation. 